\title{
Armillaria Root Rot Damage in Softwood Plantations in Ontario
}

\author{
by
}

\author{
R.D. Whitney ${ }^{1}$
}

\begin{abstract}
Armillaria root rot, caused most likely by Armillaria obscura (Pers.) Herink, killed 6- to 21-year-old white spruce, black spruce, jack pine and red pine saplings in each of 49 plantations examined in northern Ontario. Annual mortality in the four species over the last 2 to 6 years averaged $1.4 \%, 1.5 \%, 0.5 \%$ and $0.2 \%$, respectively. In all but one of 25 white spruce and red pine plantations ( 43 to 58 years old) in eastern and southern Ontario, Armillaria root rot was associated with mortality. Accumulated mortality in white spruce and red pine (initially recorded in 1978) averaged $7.6 \%$ and $11.7 \%$, respectively, as of 1986 . Current annual mortality for all plantations ranged from $0 \%$ to $16 \%$.
\end{abstract}

Key words: root rot, Armillaria obscura, white spruce, black spruce, jack pine, red pine.

\section{Résumé}

Le pourridié-agaric, causé fort probablement par Armillaria obscura (Pers.) Herink, est à l'origine de la mortalité d'Epinettes blanches, d'Epinettes noires, de Pins gris et de Pins rouges âgés de 6 à 21 ans dans 49 plantations situées dans le nord de l'Ontario. Au cours des 2 à 6 dernières années, les taux de mortalité annuels moyens ont été respectivement de $1.4 \%, 1.5 \%$, $0.5 \%$ et $0.2 \%$ chez les quatre espèces. La mortalite des arbres est due au pourridié-agaric dans 24 des 25 plantations d'Epinettes blanches et de Pins rouges (âgés de 43 à 58 ans) évaluées dans l'est et le sud de l'Ontario. Les taux de mortalité cumulatifs moyens des Epinettes blanches et des Pins rouges (calculés depuis 1978) étaient respectivement de $7.6 \%$ et de $11.7 \%$ en 1986. A l'heure actuelle, le taux de mortalité annuel varie de $0 \%$ à $16 \%$ dans toutes les plantations.

Mots clés: pourridié-agaric, Armillaria obscura, Epinette blanche, Epinette noire, Pin gris, Pin rouge

\section{Introduction}

Armillaria root rot-induced mortality has been observed in all conifers planted in Ontario (Anon. 1970-1983). Armillaria mellea (Vahl. ex Fr.) Kummer ${ }^{2}$ was the main root-rotting fungus in dying conifer saplings of natural regeneration at several locations throughout Ontario (Whitney and Myren 1978). Huntley et al. (1961) found that up to $29 \%$ of planted white pine (Pinus strobus L.) and red pine ( $P$. resinosa Ait.), growing near hardwood stumps, were killed by $A$. mellea2 21 years after planting. The same study reported that $55 \%$ of the trees were dead 31 years after planting. Forest Insect and Disease Survey records (Anon. 1970-1983) show up to $27 \%$ mortality in red pine plantations. Many plantations of white

\footnotetext{
Canadian Forestry Service, Great Lakes Forestry Centre, P.O. Box 490, Sault Ste. Marie, Ontario, Canada P6A 5M7

2 Probably A. obscura (Pers.) Herink

3 Isolates of Armillaria from the roots of white spruce and black spruce from some 60 plots in natural stands across northern Ontario were identified by Dr. D.

Morrison (Pacific Forestry Centre. Victoria. British Columbia) as Armillaria ostoyae (Romagn.) Herink, which is now considered synonymous with $A$. obscura (Pers.) Herink, (Roll-Hansen 1985). Pairings of single-spore isolates from northern Ontario sporophores by Dr. M.T. Dumas (Great Lakes Forestry Centre. Sault Ste. Marie, Ontario) have confirmed that the northern Ontario samples are A. obscura and have also identified that this species is present in 60 -year-old red pine in southern Ontario.
}

spruce (Picea glauca [Moench] Voss), black spruce $(P$. mariana [Mill.] B.S.P.), jack pine (Pinus banksiana Lamb.), white pine ( $P$. Strobus L.), lodgepole pine ( $P$. contorta Dougl.) and Scots pine ( $P$. sylvestris $L$.) have also shown mortality as a result of the presence of Armillaria root rot.

Since the discovery of the complex of Armillaria species and related biological forms by Korhonen (1978) in Europe and by Anderson and Ullrich (1979) in North America, a measure of uncertainty has been created about the identity of the species/forms of Armillaria present in Ontario. The species that is known to attack conifers in Ontario and is being discussed in this report is most likely $A$. obscura (Pers.) Herink. $^{3}$

Surveys based on systematic tree selection from a random start in "high-value" Ontario plantations indicate that low proportions $(1-2 \%)$ of trees are killed, and that many plantations have no Armillaria root rot at all (H.L. Gross and P.D. Syme, Great Lakes Forestry Centre, Sault Ste. Marie, Ont., unpublished data). It seems that the occurrence of Armillaria root rot is sporadic and results in groups of dead trees. Stocking of the desired species can be far from adequate where large openings (10-30 m diameter) occur in the forest, or where groups of 5 to 10 dead trees are frequent. This makes 
it difficult to estimate damage resulting from the disease. This study was undertaken in an attempt to improve our knowledge of losses caused by Armillaria root rot in conifer plantations in Ontario.

\section{Methods}

One plot was located in each of 49 plantations planted between 1960 and 1980, and in each of 25 older plantations established between 1925 and 1940 .

Young plantations (planted between 1960 and 1980) of white spruce $(n=15)$, black spruce $(n=11)$, jack pine $(n=15)$ and red pine $(n=11)$ were selected in widely separated areas in northern and eastern Ontario. The investigations extended from Nipigon in the west to Temagami in the eastern part of the province. Moderately well stocked stands aged 6 to 21 years were sampled. In a selected area considered to be representative of the plantation, a 0.2 -ha plot $(20 \mathrm{~m} \times 100 \mathrm{~m})$ was laid out, marked with wooden plot corner posts, and located on a map. All living and dead trees were tallied. Wherever root rot was suspected as the killing agent, the basal bark of dead trees was peeled back and a few roots were excavated or exposed. Tree death was attributed, at least in part, to Armillaria root rot when mycelial fans or rhizomorphs were observed under root bark or under bark in the root collar area (Fig. 1), or when Armillaria sporophores were seen attached to the base of dead trees (Fig. 2). Trees in which mortality or damage was attributable to other causes were excluded from the tally. Dead trees were located and marked with paint to avoid retallying them at the next 2-year evaluation. Initial mortality counts were made in the plantations at various times between 1979 and 1983. Following the initial assessment, additional Armillaria-caused mortality was tallied every two years except in a red pine plantation in Davis Twp. Thus, plots established in 1979 were reassessed for mortality in 1981, 1983 and 1985. Those established in 1983 were reassessed only once - in 1985.

Older plantations (planted between 1925 and 1940 in eastern and southern Ontario) of white spruce and red pine were also sampled. Plots (0.2 ha) were established in 1983 for biennial examination. Plots at Petawawa were an exception, as they were superimposed on .08-ha plots, usually square. Bark of the lower bole, root collar and larger roots of older, dead trees was removed; the presence of mycelial fans or rhizomorphs on the cambium was considered to be a sign of Armillaria root rot (Fig. 3). The cause of death of older trees was not easily determined in many cases. The older dead trees with Armillaria root rot infection frequently revealed signs of bark beetles ${ }^{4}$, as indicated by galleries and exit holes.

\section{Results}

\section{Young Plantations (Planted between 1960 and 1980)}

In chlorotic or recently dead trees of all species, mycelial fans of Armillaria usually encircled the base of the tree. However, in trees dead for about 3 years, only fragments of the mycelial fans were'observed in most cases.

In 15 white spruce plantations aged 6 to 20 years, mortality from Armillaria root rot at the time of plot establishment ranged from $0.3 \%$ to $17.3 \%$ (an average of

${ }_{4}^{4}$ Identified as Ips pini (Say) by P.D. Syme, Entomologist, Great Lakes Forestry Centre, Sault Ste. Marie, Ontario

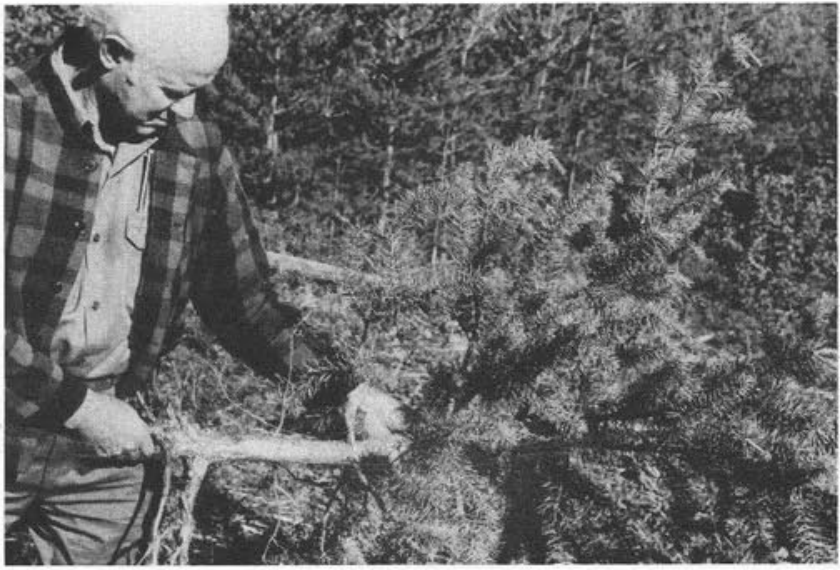

Figure 1. Mycelial fans of Armillaria spp. girdled the base of chlorotic 7-year-old jack pine, causing chlorosis.

$3.7 \%$ ) of total trees planted (Table 1). Dead trees were mostly scattered throughout the plantation, but groups of two or three dead trees were often observed. Occasionally, larger groups of dead trees were observed, forming gaps in the stand. Additional mortality over three subsequent 2-year periods ranged from 0 to $10.1 \%$ per period. Mortality after the plots were established (at various times) averaged $1.4 \%$ per year. These dead trees were most frequently found adjacent to trees killed earlier. Accumulated mortality, including that observed during the initial assessment, averaged $10.2 \%$ of white spruce trees per plot (Table 1).

On the 11 black spruce plantations, initial mortality due to Armillaria root rot ranged from 0 to $13.0 \%$ (avg 5.0\%) of total trees (Table 2). Most dead black spruce were also scattered. Mortality over three additional 2 -year periods averaged $2.6 \%$, $3.5 \%$ and $3.5 \%$, respectively, so that average annual mortality was $1.5 \%$ (Table 2), a rate almost identical to that for white spruce. Average accumulated mortality from Armillaria root rot in black spruce was $14.6 \%$ per plot after the initial assessment in 1979 .

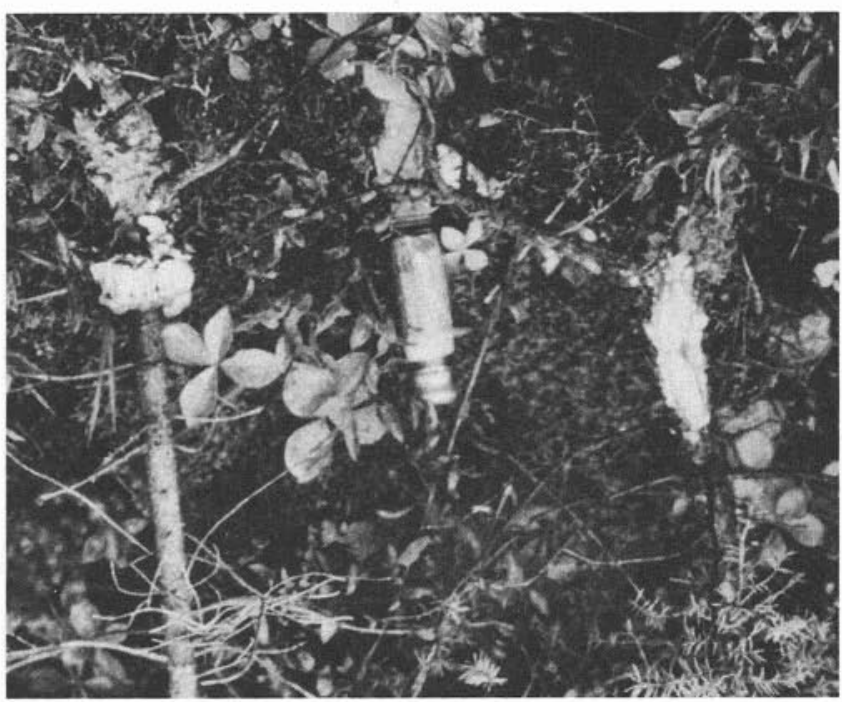

Figure 2. Eight-year-old black spruce near Chipman Lake, Ontario, infected with Armillaria spp. Left, an infected, living tree; right, a dead tree with sporophores around its base. 


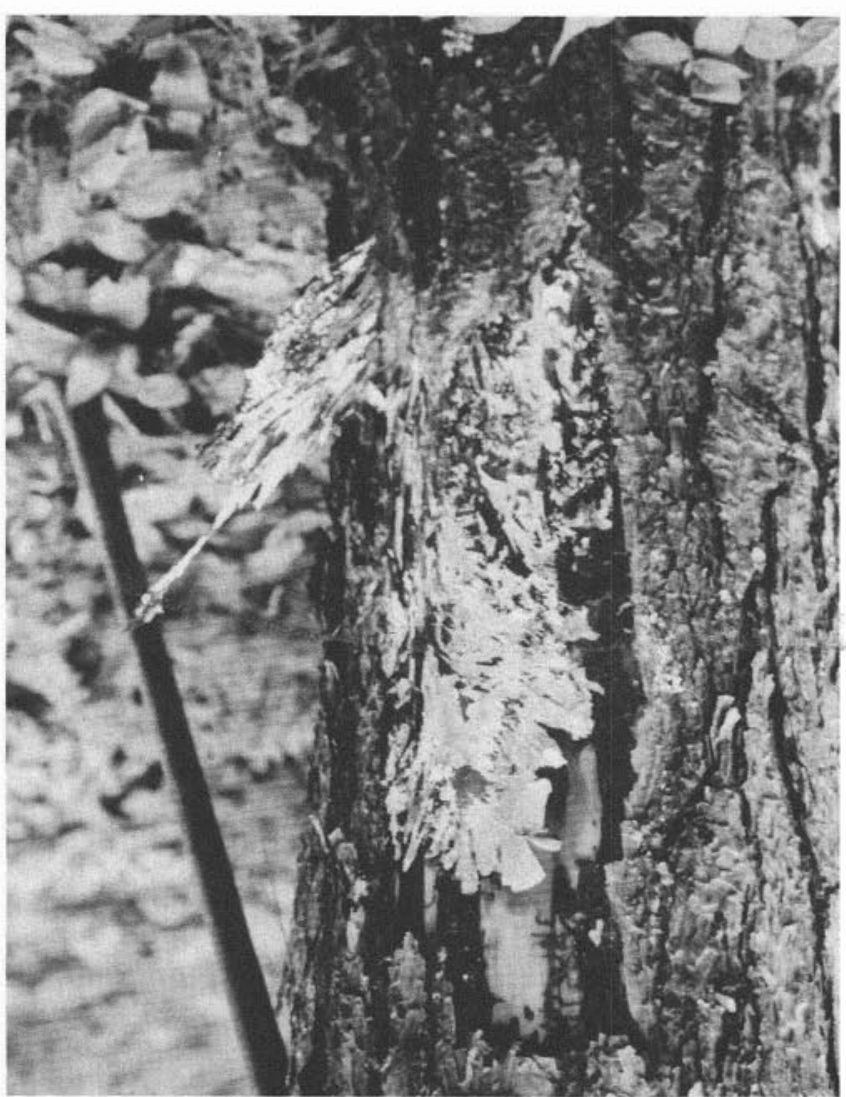

Figure 3. Mycelial fans of Armillaria spp. at the base of chlorotic 45year-old red pine, York County Forest, Ontario.
Initial mortality in young jack pine due to Armillaria root rot ranged from $0.6 \%$ to $10.2 \%$ (an average of $2.5 \%$ ) in 15 plantations (Table 3). Subsequent mortality in jack pine over three ensuing 2 -year periods ranged up to $4.2 \%$ per period. Accumulated average mortality in all jack pine plantations over the survey period was $6.2 \%$. Average annual mortality was only $0.5 \%$ (Table 3 ). Dead jack pine were usually scattered throughout the stands in a manner similar to that of the spruces.

Young red pine plantations showed the least mortality owing to Armillaria root rot. Initial mortality ranged from $0.2 \%$ to $13.7 \%$ of all trees killed (Table 4). Average annual mortality 2 years later was below $1 \%$ in all plantations, with the exception of Kennedy Creek plantation near Wawa, where annual mortality was $16 \%$.

Regression analyses indicated that plantation density and year of sampling had no influence on mortality caused by Armillaria root rot. Among the younger plantations, however, plantation age significantly affected the proportions of white spruce trees killed by this disease. Figure 4 indicates that more Armillaria-killed trees were found in the youngest ( 6 and 7 years old) plantations than in plantations 10 to 20 years old. However, the correlation is low $(r=.54)$. Examination of individual plantations in Tables 1 and 2 showed that there was a downward trend in Armillaria-caused mortality over a 5- or 6 -year period in about $25 \%$ of the plots. This was most common in stands of white spruce, and several black spruce plantations showed the opposite trend.

\section{Older Plantations (Planted between 1925 and 1940)}

Table 5 shows that Armillaria-caused mortality ranged from $0.3 \%$ to $15.4 \%$ of the stand in nine older $(45-53 \mathrm{yr})$ red

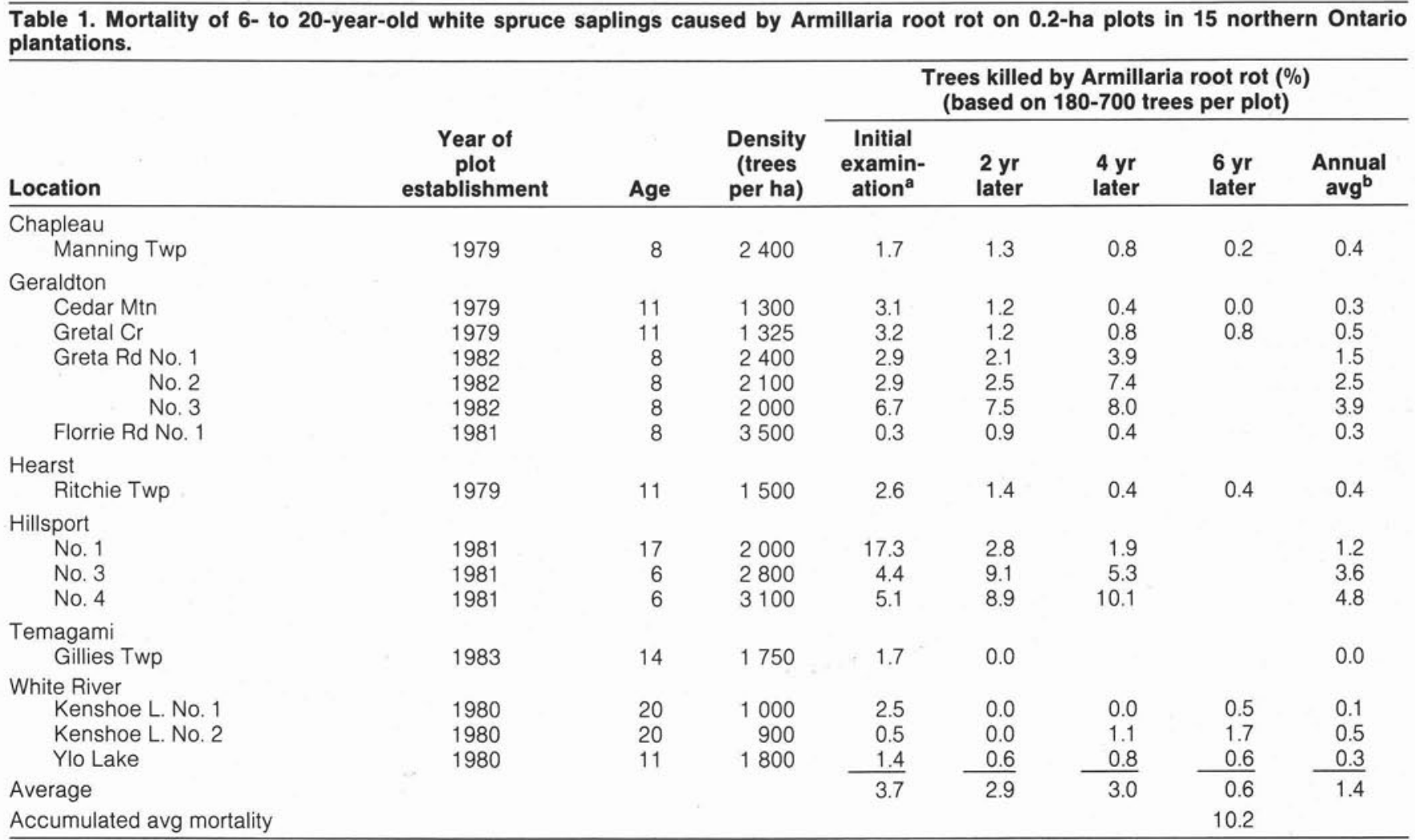

${ }_{\text {a }}$ mortality recorded at time of plot establishment

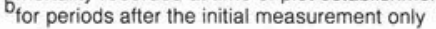




\begin{tabular}{|c|c|c|c|c|c|c|c|c|}
\hline \multirow[b]{2}{*}{ Location } & \multirow[b]{2}{*}{$\begin{array}{c}\text { Year of } \\
\text { plot } \\
\text { establishment }\end{array}$} & \multirow[b]{2}{*}{ Age } & \multirow[b]{2}{*}{$\begin{array}{c}\text { Density } \\
\text { (trees } \\
\text { per ha) }\end{array}$} & \multicolumn{5}{|c|}{$\begin{array}{l}\text { Trees killed by Armillaria root rot (\%) } \\
\text { (based on } 160-940 \text { trees per plot) }\end{array}$} \\
\hline & & & & $\begin{array}{l}\text { Initial } \\
\text { examin- } \\
\text { ation }^{a}\end{array}$ & $\begin{array}{l}2 \mathrm{yr} \\
\text { later }\end{array}$ & $\begin{array}{l}4 \mathrm{yr} \\
\text { later }\end{array}$ & $\begin{array}{l}6 \text { yr } \\
\text { later }\end{array}$ & $\begin{array}{c}\text { Annual } \\
\text { avg }^{\mathrm{b}}\end{array}$ \\
\hline Geraldton & & & & & & & & \\
\hline Florrie Rd No. 5 & 1982 & 9 & 4700 & 5.5 & 4.1 & & & 2.1 \\
\hline $\begin{array}{l}\text { Florrie Rd No. } 6 \\
\text { Oly Lake }\end{array}$ & $\begin{array}{l}1981 \\
1980\end{array}$ & $\begin{array}{r}8 \\
10\end{array}$ & $\begin{array}{l}3200 \\
1700\end{array}$ & $\begin{array}{r}3.2 \\
13.0\end{array}$ & $\begin{array}{l}0.3 \\
3.0\end{array}$ & $\begin{array}{l}2.6 \\
3.5\end{array}$ & & $\begin{array}{l}0.7 \\
1.6\end{array}$ \\
\hline $\begin{array}{l}\text { Kapuskasing } \\
\text { Opasatica Twp }\end{array}$ & 1979 & 9 & 3800 & 0.0 & 0.0 & 3.7 & 4.3 & 1.3 \\
\hline $\begin{array}{l}\text { Wawa } \\
\quad \text { Kennedy Cr No. } 3\end{array}$ & 1980 & 7 & 1400 & 5.8 & 8.8 & 11.8 & 8.1 & 4.8 \\
\hline $\begin{array}{l}\text { White River } \\
\text { Cupa Lake } \\
\text { Elsie Lake No. } 2 \\
\text { Elsie Lake No. } 3 \\
\text { Elsie Lake No. } 4 \\
\text { Kenshoe Lake No. } 2\end{array}$ & $\begin{array}{l}1980 \\
1980 \\
1980 \\
1980 \\
1980\end{array}$ & $\begin{array}{r}12 \\
8 \\
8 \\
8 \\
20\end{array}$ & $\begin{array}{r}2200 \\
1500 \\
1750 \\
1650 \\
800\end{array}$ & $\begin{array}{l}2.7 \\
6.2 \\
6.9 \\
5.4 \\
1.2\end{array}$ & $\begin{array}{l}0.9 \\
2.6 \\
4.2 \\
2.2 \\
0.0\end{array}$ & $\begin{array}{l}1.2 \\
2.6 \\
5.3 \\
0.7 \\
0.6\end{array}$ & $\begin{array}{l}1.0 \\
2.7 \\
6.0 \\
2.6 \\
0.0\end{array}$ & $\begin{array}{l}0.5 \\
1.3 \\
2.6 \\
0.9 \\
0.1\end{array}$ \\
\hline $\begin{array}{l}\text { Average } \\
\text { Accumulated avg mortality }\end{array}$ & & & & $\overline{5.0}$ & $\overline{2.6}$ & $\overline{3.5}$ & $\begin{array}{r}3.5 \\
14.6\end{array}$ & $\overline{1.5}$ \\
\hline
\end{tabular}

$a_{\text {recorded at time of plot establishment. }}$

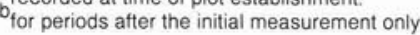

pine plantations in 1983. In most cases, the dead trees were in small groups of two to five trees. Occasionally, larger groups of trees were also killed (Fig. 5). Mycelial fans were abundant between bark and xylem tissues. In some recently dead trees, mycelial fans were found as high as 2-3 m up the trunk, and sporophores were produced from this region. Sporophores and small amounts of subcortical mycelium at ground level or slightly above ground level were also observed on some trees that showed no symptoms of decline in the crown (Fig. 6). Average annual mortality due to Armillaria root rot in older red pine plantations varied from $0.0 \%$ to $4.5 \%$ in 1984 and 1985 (Table 5).

Twelve of the 14 older white spruce plantations examined were in the well-studied experimental plantations at Petawawa. As with red pine, there was considerable variation

Table 3. Mortality of 6- to 21-year-old jack pine saplings caused by Armillaria root rot on 0.2-ha plots in 15 Ontario plantations.

\begin{tabular}{|c|c|c|c|c|c|c|c|c|}
\hline \multirow[b]{2}{*}{ Location } & \multirow[b]{2}{*}{$\begin{array}{c}\text { Year of } \\
\text { plot } \\
\text { establishment }\end{array}$} & \multirow[b]{2}{*}{ Age } & \multirow[b]{2}{*}{$\begin{array}{c}\text { Density } \\
\text { (trees } \\
\text { per ha) }\end{array}$} & \multicolumn{5}{|c|}{$\begin{array}{l}\text { Trees killed by Armillaria root rot (\%) } \\
\text { (based on 60-840 trees per plot }\end{array}$} \\
\hline & & & & $\begin{array}{l}\text { Initial } \\
\text { examin- } \\
\text { ation }^{\mathrm{a}}\end{array}$ & $\begin{array}{l}2 \mathrm{yr} \\
\text { later }\end{array}$ & $\begin{array}{l}4 \mathrm{yr} \\
\text { later }\end{array}$ & $\begin{array}{l}6 \text { yr } \\
\text { later }\end{array}$ & $\begin{array}{c}\text { Annual } \\
\text { avg }^{\mathrm{b}}\end{array}$ \\
\hline $\begin{array}{l}\text { Espanola } \\
\text { Dunlop Twp } \\
\text { Mandamin Twp } \\
\text { Moses Twp } \\
\text { Nairn Twp No. } 1 \\
\text { Nairn Twp No. } 2 \\
\text { Tennyson Twp No. } 1\end{array}$ & $\begin{array}{l}1983 \\
1983 \\
1983 \\
1983 \\
1983 \\
1983\end{array}$ & $\begin{array}{l}21 \\
21 \\
20 \\
20 \\
20 \\
13\end{array}$ & $\begin{aligned} 550^{c} \\
300^{c} \\
2450 \\
2130 \\
750^{c} \\
2500\end{aligned}$ & $\begin{array}{r}2.9 \\
3.3 \\
10.2 \\
2.1 \\
2.0 \\
1.4\end{array}$ & $\begin{array}{l}0.9 \\
0.0 \\
2.1 \\
1.0 \\
0.0 \\
2.0\end{array}$ & & & $\begin{array}{l}0.5 \\
0.0 \\
1.0 \\
0.5 \\
0.0 \\
1.0\end{array}$ \\
\hline $\begin{array}{l}\text { Temagami } \\
\text { Gamble Twp } \\
\text { McGiffin Twp }\end{array}$ & $\begin{array}{l}1983 \\
1983\end{array}$ & $\begin{array}{l}14 \\
12\end{array}$ & $\begin{array}{l}2700 \\
2700\end{array}$ & $\begin{array}{l}1.8 \\
1.7\end{array}$ & $\begin{array}{l}0.2 \\
0.2\end{array}$ & & & $\begin{array}{l}0.1 \\
0.1\end{array}$ \\
\hline $\begin{array}{l}\text { Wawa } \\
\text { Challenor Twp } \\
\text { Kennedy Cr No. } 1 \\
\text { Kennedy Cr No. } 2 \\
\text { Kennedy Cr No. } 3\end{array}$ & $\begin{array}{l}1980 \\
1980 \\
1980 \\
1980\end{array}$ & $\begin{array}{l}9 \\
6 \\
6 \\
6\end{array}$ & $\begin{array}{l}4200 \\
3000 \\
1000 \\
2000\end{array}$ & $\begin{array}{l}1.7 \\
3.1 \\
2.6 \\
1.5\end{array}$ & $\begin{array}{l}0.8 \\
1.9 \\
4.0 \\
3.5\end{array}$ & $\begin{array}{l}0.7 \\
1.1 \\
0.0 \\
4.2\end{array}$ & $\begin{array}{l}1.6 \\
0.9 \\
3.7 \\
1.1\end{array}$ & $\begin{array}{l}0.5 \\
0.7 \\
1.3 \\
1.5\end{array}$ \\
\hline $\begin{array}{l}\text { Average } \\
\text { Accumulated avg mortality }\end{array}$ & & & & $\overline{2.5}$ & $\overline{1.3}$ & $\overline{1.1}$ & $\begin{array}{l}1.3 \\
6.2\end{array}$ & $\overline{0.5}$ \\
\hline
\end{tabular}

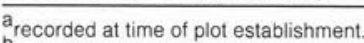

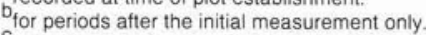

Cnatural-seeded on a red pine plantation. 
Trees killed by Armillaria root rot $(\%)$

(based on 250-450 trees per plot)

\begin{tabular}{|c|c|c|c|c|c|c|c|}
\hline \multirow[b]{2}{*}{ Location } & \multirow[b]{2}{*}{$\begin{array}{c}\text { Year of } \\
\text { plot } \\
\text { establishment }\end{array}$} & \multirow[b]{2}{*}{ Age } & \multirow[b]{2}{*}{$\begin{array}{c}\text { Density } \\
\text { (trees } \\
\text { per ha) }\end{array}$} & \\
\hline & & & & $\begin{array}{l}\text { Initial } \\
\text { examin- } \\
\text { ation }^{\mathrm{a}}\end{array}$ & $\begin{array}{c}2 \text { yr } \\
\text { later }\end{array}$ & $\begin{array}{l}4 \mathrm{yr} \\
\text { later }\end{array}$ & $\begin{array}{c}\text { Annual } \\
\text { avg }^{\mathrm{b}}\end{array}$ \\
\hline \multicolumn{8}{|l|}{ Espanola } \\
\hline Dunlop Twp & 1983 & 21 & 1400 & 2.5 & 0.4 & & 0.2 \\
\hline Mandamin Twp & 1983 & 21 & 1250 & 0.8 & 0.0 & & 0.0 \\
\hline Moses Twp & 1983 & 20 & 1600 & 0.6 & 0.0 & & 0.0 \\
\hline Nairn Twp No. 2 & 1983 & 20 & 1350 & 2.2 & 0.8 & & 0.4 \\
\hline Weeks Twp & 1983 & 21 & 1250 & 1.6 & 0.0 & & 0.0 \\
\hline \multicolumn{8}{|l|}{ Temagami } \\
\hline Biggs Twp & 1983 & 13 & 1700 & 0.3 & 0.0 & & 0.0 \\
\hline Gilles Twp & 1983 & 14 & 2000 & 0.2 & 1.0 & & 0.5 \\
\hline \multicolumn{8}{|l|}{ Hagar } \\
\hline Davis Twp No. 1 & 1986 & 6 & 1445 & 2.4 & & & \\
\hline No. 2 & 1986 & 6 & 1780 & 2.2 & & & \\
\hline No. 3 & 1986 & 6 & 2255 & 2.4 & & & \\
\hline \multicolumn{8}{|l|}{ Wawa } \\
\hline Kennedy Cr No. 2 & 1982 & 8 & 2200 & 13.7 & 25.2 & 38.7 & 16.0 \\
\hline Average $^{c}$ & & & & $\overline{1.5}$ & $\overline{0.3}$ & & 0.2 \\
\hline Accumulated avg mortality ${ }^{c}$ & & & & & 1.8 & & \\
\hline
\end{tabular}

a recorded at time of plot establishment.

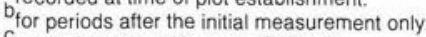

excluding plot at Kennedy $\mathrm{Cr}$ No. 2.
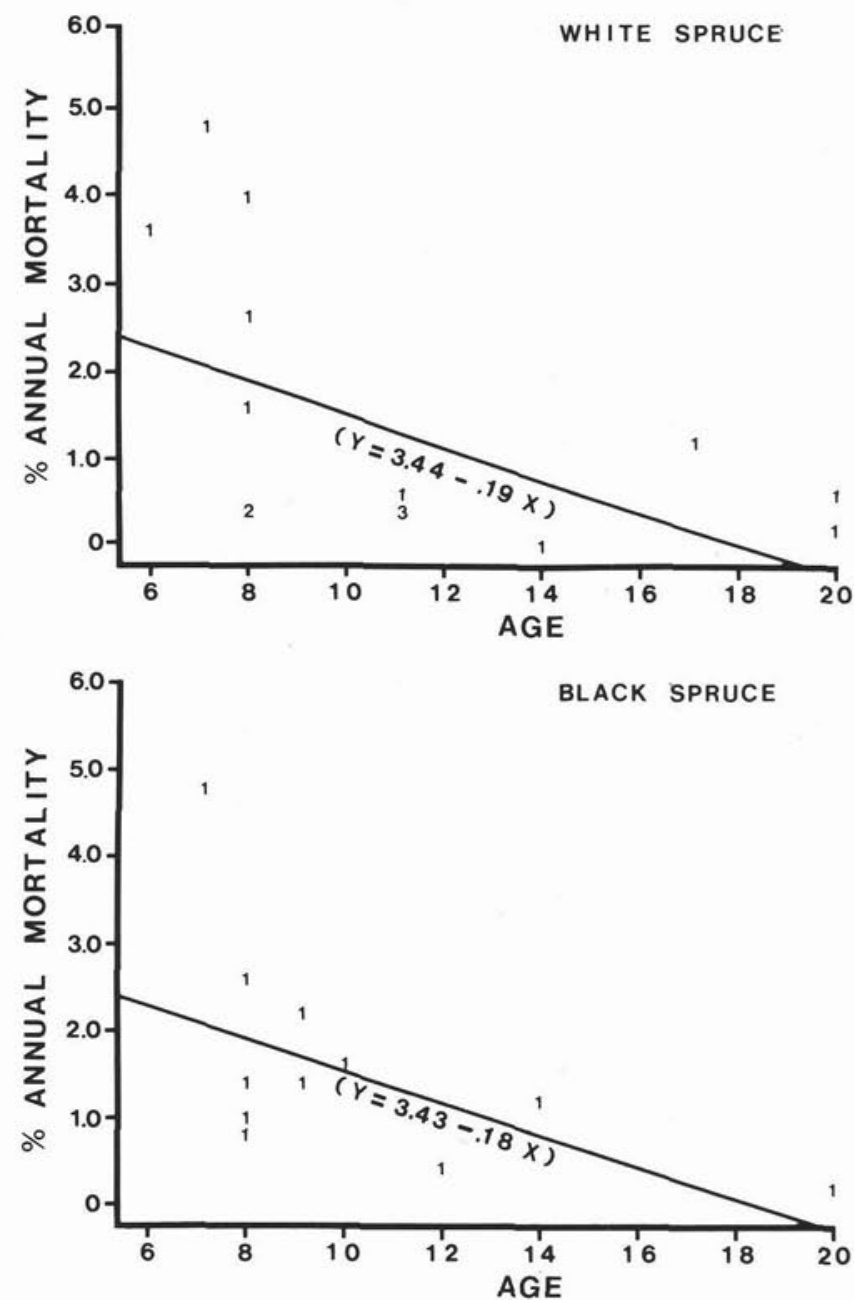

Figure 4. Percentage of white spruce and black spruce saplings killed annually by Armillaria root rot $(Y)$ at various ages $(X)$ in Ontario plantations. in mortality as a result of Armillaria root rot in older white spruce. Mortality ranged from $0 \%$ in plantation 67D to $19.4 \%$ in plantation 14A (Table 6). Average annual mortality in 1984 and 1985 varied from $0 \%$ (in five plantations) to $2.7 \%$ of stems killed at Durham, .

\section{Discussion}

Armillaria root rot killed trees in all but one of 72 conifer plantations examined (67D at Petawawa). In plantations less than 25 years old, diagnosis of root rot was certain because it was not confounded by the presence of other pests or declines. Where fewer than $1 \%$ of trees were killed annually in young plantations, losses were insignificant, as long as the mortality was evenly distributed in the stand. However, where the root rot occurred in patches, understocking resulted. Understocking was evident in six of 15 white spruce, seven of 11 black spruce, four of 15 jack pine and one of eight red pine plantations. After a detailed study in radiata pine (Pinus radiata D. Don) plantations in New Zealand, Van der Pas (1981) concluded that, rather than increasing radially, infection centres delineated root systems of old-growth stumps and other root systems that supplied Armillaria inoculum. This association of killed trees with below-ground inoculum seems to be present in Ontario as well.

Whether the current rate of mortality from Armillaria root rot will increase, decrease, or remain constant in a plantation is unpredictable on the basis of present knowledge. Examples of all three conditions in plantations can be seen in the data presented. However, only initial trends can be established on the basis of two or three observations per plantation made to date.

Both jack pine and red pine saplings sampled seemed less susceptible to Armillaria than the spruces. Of the pines, red pine saplings were attacked less than jack pine, except at Kennedy Creek. The high proportion of red pine killed by Armillaria root rot at Kennedy Creek was comparable to that observed earlier by Huntley et al. (1961) in 31-year-old trees. 
Table 5. Mortality of 43- to 53-year-old semimature red pine caused by Armillaria root rot on 0.2-ha plots (except at Petawawa) ${ }^{a}$ in 11 southern and eastern Ontario plantations.

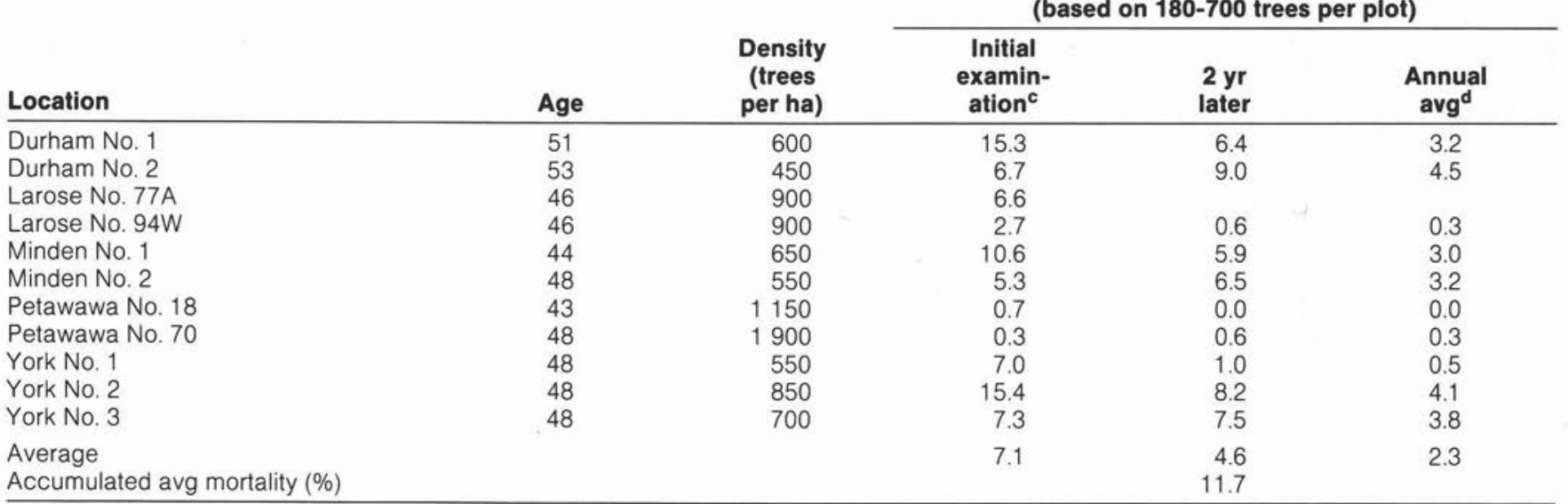

a Plots in Petawawa plantations were 0.08 ha.

Some dead trees were also infested with bark beetles.

recorded at time of plot establishment in 1983.

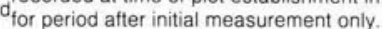

In the earlier study, the high rate of infection of planted trees was attributed to their proximity to hardwood stumps that were suspected of Armillaria infection. In Kennedy Creek plantations, apparently a similar situation prevails, even though the stumps are of softwood species.

In other parts of Canada, Morrison (1981) found that Armillaria root rot results in death of $2 \%$ to $3 \%$ of young western hemlock (Tsuga heterophyla [Raf.] Sarg.) and Douglas-fir (Pseudotsuga menziesii [Mirb.] Franco) 5 to 25 years of age in coastal British Columbia forests. Hiratsuka (1987) considers this root rot to be important in plantations or highly managed stands in the Prairie Provinces, where it tends to kill young trees in groups and thus creates undesirable gaps in stands. In Newfoundland, Singh and Richardson (1973) found that the percentage of trees infected by Armillaria sp. ranged from $1.8 \%$ to $79.0 \%$ among 17 conifers (mostly exotics) tested in experimental plantations.

According to Wargo and Shaw (1985), a critical evaluation of disease impact and of forest management objectives is required to ensure that the level of loss justifies

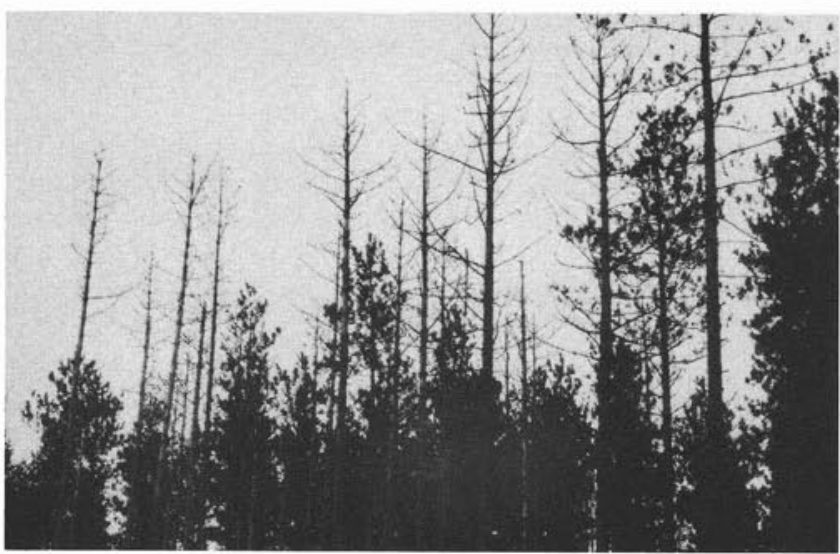

Figure 5. Forty-year-old red pine near Midhurst, Ontario, killed by Armillaria root rot. any control measures. In the present investigations an attempt was made to assess the damage, and it appears that reduction of inoculum sources may be the most suitable means of controlling the disease. Morrison (1981) recommended stump removal and root raking to remove Armillaria-infested material before regenerating diseaseaffected areas in the interior of British Columbia. He also suggested that, if possible, planting or regenerating the most susceptible species (Abies spp., Douglas-fir, and western hemlock) be avoided. There is some evidence from this study that jack pine and red pine may be less susceptible to the disease than white spruce and black spruce. To avoid losses to Armillaria root rot in Newfoundland, Singh and Richardson (1973) recommended seeding non-stocked forest land (or

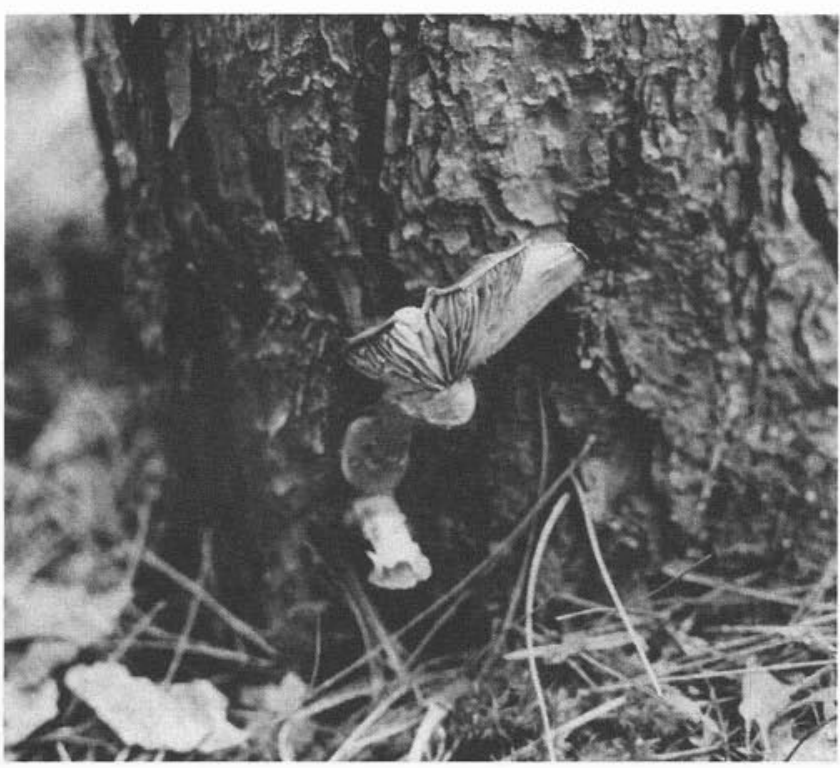

Figure 6. Sporophore of Armillaria spp. at the base of 40-year-old, healthy-appearing red pine. Midhurst, Ontario, 23 October 1985. 
Table 6. Mortality of 43- to 58-year-old semimature white spruce caused by Armillaria root rot on 0.08 (Petawawa) to 0.2 -ha plots in 14 southern and eastern Ontario plantations.

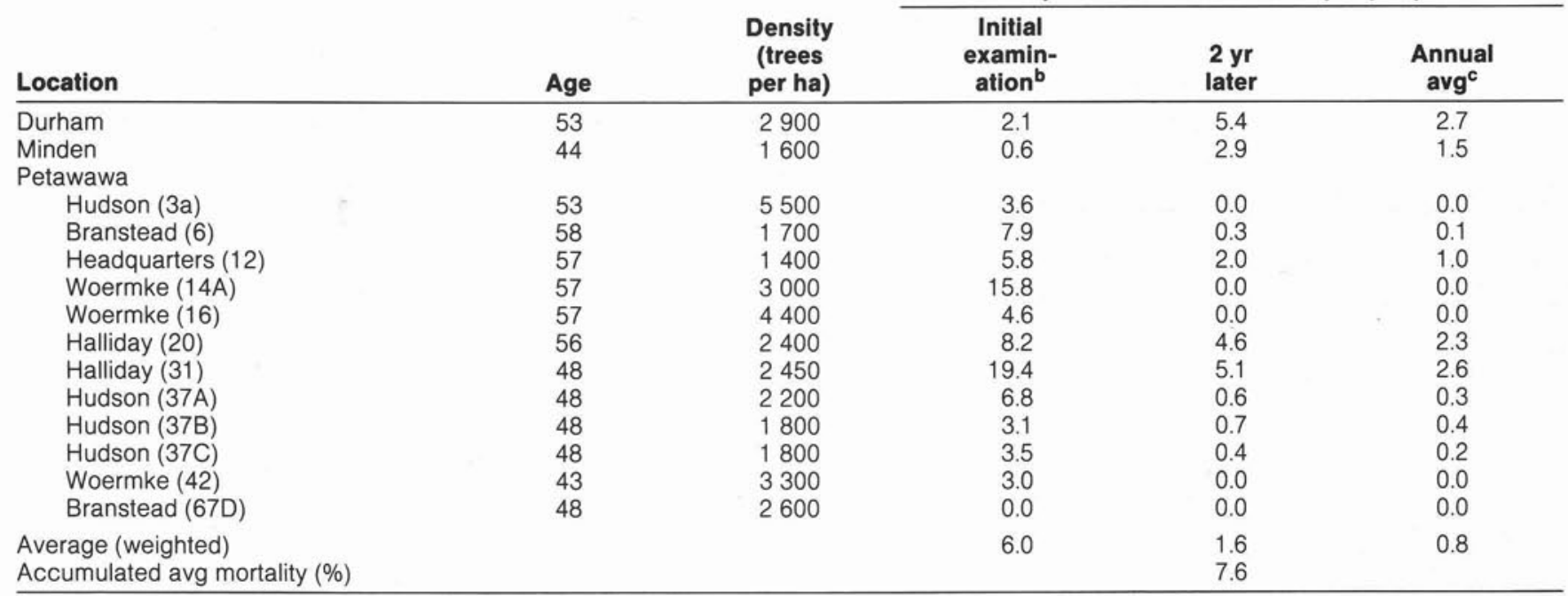

${ }_{\text {S }}$ Some dead trees had also been infested with bark beetles.

recorded at time of plot establishment in 1983

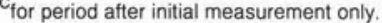

perhaps container planting) rather than planting bare-root stock, and using native species in reforestation.

In one older plantation (Larose 94W), annosus root rot (Myren 1973) was present as well as Armillaria root rot, and this disease is known to damage pine plantations in southern Ontario (ibid.). Limestone-induced chlorosis (Ellis and Whitney 1975) is associated with mortality in older red pine plantations in eastern Ontario. In some plantations at Petawawa, heavy snow (e.g., in the winter of 1978-1979 [Stiell 1980]) had caused broken tops, and the damaged trees were dying and becoming invaded by Armillaria. These trees were not included in Tables 5 and 6 , as the snow breakage was considered the primary cause of death. Armillaria root rot, however, may have hastened death. Broken tops contribute to stress in trees, and some researchers (Patton and Vasquez Bravo 1967) contend that this would increase their susceptibility to Armillaria attack.

Armillaria-associated root rot in red pine at Petawawa plantations was considerably less severe than in red pine plantations at the other four eastern and southeastern Ontario locations. Furthermore, the older red pines in the Petawawa plantations appeared to be damaged much less than white spruce. This difference confirmed the findings for these species in younger plantations. In the older white spruce plantations, mostly at Petawawa, mortality due to Armillaria root rot varied considerably, ranging from $0 \%$ to $19.4 \%$ as evaluated in 1983.

\section{Acknowledgments}

I wish to thank Forest Management Supervisors and Unit Foresters of the Ontario Ministry of Natural Resources in the forest districts where the plots are situated, and W.M. Stiell (now retired), Petawawa National Forestry Institute, for assistance in locating plantations and for providing relevant information on them; B.E. Smith, Great Lakes Forestry Centre (Sault Ste. Marie, Ontario) for locating sample plots and performing evaluations of the root rot throughout the study; and W.E. Britnell and R. Irwin of the same Centre for evaluating root rot from 1984 to 1986

\section{References}

Anderson, J.B. and R.C. Ullrich. 1979. Biological species of Armillaria mellea in North America. Mycologia 71: 402-414.

Anon. 1970-1983. Annual Report of the Forest Insect and Disease Survey. Dep. Environ., Can. For. Serv., Ottawa, Ont.

Ellis, R.C. and R.D. Whitney. 1975. Preliminary observations on mortality of red pine on a calcareous soil in southern Ontario. Dep. Environ., Can. For. Serv., Ottawa, Ont. Bi-mon. Res. Notes 31(4): 27-29.

Hiratsuka, Y. 1987. Forest tree diseases of the prairie provinces. Can. For. Serv., Edmonton, Alta. Inf. Rep. NOR-X-286. 142 p.

Huntley, J.H., J.D. Cafley and E. Jorgensen. 1961. Armillaria root rot in Ontario. For. Chron. 37: 228-236.

Korhonen, K. 1978. Interfertility and clonal size in the Armillaria mellea complex. Karstenia 18: 31-42.

Morrison, D.J. 1981. Armillaria root disease: a guide to disease diagnosis, development, and management in British Columbia. Dep. Environ., Can. For. Serv., Victoria, B.C. Inf. Rep. BC-X-203. $15 \mathrm{p}$.

Myren, D.T. 1973. The intensification of red pine infection by Fomes annosus within the St. Williams Forest Station. Dep. Environ., Can. For. Serv., Sault Ste. Marie, Ont. Inf. Rep. O-X-184. 5 p.

Patton, R.F. and R. Vasquez Bravo. 1967. Armillaria mellea (Vahl. ex. Fr.) Kummer. p. 36-38 in A.G. Davidson and R.M. Prentice, (Ed.) Important forest insects and diseases of mutual concern to Canada, the United States, and Mexico. Can. Dep. For. Rur. Dev., Ottawa, Ont.

Roll-Hansen, F. 1985. The Armillaria species in Europe. A literature review. Eur. J. For. Pathol. 15: 22-31.

Singh, P. and J. Richardson. 1973. Armillaria root rot in seeded and planted areas in Newfoundland. For. Chron. 49: 180-182.

Stiell, W.M. 1980. Response of white spruce plantations to three levels of thinning from below 1958-1978. For. Chron. 56:21-27.

Van der Pas, J.B. 1981. A statistical appraisal of Armillaria root rot in New Zealand plantations of Pinus radiata. N.Z. J. For. Sci. 11: 23-36.

Wargo, P.M. and C.G. Shaw III. 1985. Armillaria root rot: the puzzle is being solved. Plant Dis. 69: 826-832.

Whitney R.D. and D.T. Myren. 1978. Root rotting fungi associated with mortality of conifer saplings in northern Ontario. Can. J. For. Res. 8: 17-22. 